\title{
Covid 19 Salgınına İlişkin Tepkilerin Psikolojik Sağlamlık Açısından İncelenmesi
}

\section{Dr. Gülin Yazıcı Çelebi ${ }^{1 *}$}

Geliş tarihi: 14.05 .2020

Kabul tarihi: 10.08 .2020

\section{Atuf bilgisi: \\ IBAD Sosyal Bilimler Dergisi \\ Sayı: $8 \quad$ Sayfa: $471-483$ \\ Yıl: 2020 Dönem: Güz}

This article was checked by iThenticate. Similarity Index 13\%

Bu makalede araştırma ve yayın etiğine uyulmuştur.

${ }^{1}$ Gümüşhane Üniversitesi, Türkiye, gulin_celebi@hotmail.com

ORCID ID 0000-0002-6779-9123

* Sorumlu yazar öz

Bütün dünya bir salgın tehdidi altında ve çok bir süreçten geçiyor bu süreç bir sağlık krizi olmasının yanı sıra bir kaygı krizine de yol açmış durumda. Kaygı ve buna yönelik tepkiler üzerinde etkili olabilecek birçok değişken söz konusudur. Bazı insanlar daha yoğun kaygı yaşarken bazı insanlar ise daha soğukkanlı bir yaklaşım gösterebilmektedir. Psikolojik sağlamlık insanın olumsuzluklar karşısında gösterdiği uyum ve başa çıkabilme becerisi olarak tanımlanan bir kavramdır. Psikolojik sağlamlık kavramı her şey yolundayken ortaya çıkan ya da harekete geçen bir durum değildir. Bir yakının kaybı, ciddi bir hastalık ya da hastalık tehdidi, boşanma, doğal afetler gibi travmatik yaşantılar sonrası aktive olan bir süreç gibi düşünülebilir. $\mathrm{Bu}$ duruma salgın ve ölümcül bir virüs tehdidi de eklenebilir. $\mathrm{Bu}$ araştırmanın amacı da bireylerin Covid 19 salgınına ilişkin tepkilerinin psikolojik sağlamlık açısında incelenmesidir. Araştırmanın çalışma grubunu 332 kadın ve 167 erkek olmak üzere toplam 499 kişi oluşturmaktadır. Araştırmada veri toplama aracı olarak araştırmacı tarafindan hazırlanan kişisel bilgi formu, Covid 19 salgınına ilişkin sorulardan oluşan anket ve Doğan (2015) tarafindan geliștirilen Kısa Psikolojik Sağlamlık Ölçeği kullanılmıştır. Araştırma verileri 2020 Mart ve Nisan aylarında toplanmıştır. Veriler SPSS 24 programında analiz edilerek tablolaştırılmış ve yorumlanmıştır. Araştırma sonuçları psikolojik sağlamlık düzeyi düşük olan bireylerin bu süreçten daha olumsuz etkilendiğini göstermektedir. Covid 19 salgını sonucunda gösterilen davranışlar ve psikolojik sağlamlık düzeyi ayrıca demografik değişkenler açısından da incelenmiş ve bulgular literatür 1şığında tartışılmış ve önerilerde bulunulmuştur.

Anahtar Kelimeler: Psikolojik Sağlamlık, Cinsiyet, Covid 19 Salgını. 


\section{Investigation of Reactions to the Covid 19 Outbreak in terms of Psychological Resilience}

\section{Dr. Gülin Yazıcı Çelebi ${ }^{1 *}$}

First received: 14.05 .2020

Accepted: 10.08 .2020

\section{Citation:}

IBAD Journal of Social Sciences

Issue: 8

Pages: $471-483$

Year: 2020 Session: Fall

This article was checked by iThenticate. Similarity Index $13 \%$

\footnotetext{
${ }^{1}$ Gümüşhane Universitiy, Turkey, gulin_celebi@hotmail.com
}

ORCID ID 0000-0002-6779-9123

\section{* Corresponding Author}

\begin{abstract}
The whole world is under the threat of an epidemic and is going through a tough period. In addition to being a health crisis, this process has also paved the way for an anxiety crisis. There are many variables that can have an impact on anxiety and responses to it. While some people experience more intense anxiety, some people may take a more cold-blooded approach. Psychological resilience is defined as the conformity and coping mechanisms a person exhibits in the face of negativity. The concept of psychological resilience is not something that occurs or emerges when everything is in order. It can be considered to be a process that becomes activated after traumatic events, such as the loss of a loved one, a serious illness or the threat of one, divorce, or natural disasters. An epidemic and the threat of a deadly virus can also add to this situation. The purpose of this research is to examine individuals' reactions to the Covid-19 outbreak in terms of psychological resilience. The study group consisted of a total of 499 people, including 332 women and 167 men. In this study, a personal information form prepared by the researcher, a survey consisting of questions related to the Covid-19 outbreak, and a short form related to psychological resilience developed by Dogan (2015) were used as means of collecting data. Research data was collected in March and April 2020. Data were analyzed using SPSS 24 and the results were interpreted as tables. The results of the research show that individuals with low psychological resilience are affected more negatively by this process. The behaviors and level of psychological resilience exhibited as a result of Covid-19 were also examined in terms of demographic variables, and the findings were discussed in light of the literature.
\end{abstract}

Keywords: Psychological Resilience, Gender, Covid 19 Epidemic 


\section{GíRiş}

COVID 19, Çin'in Vuhan Eyaleti'nde ortaya çıkan ve yapılan araştırmalar sonucunda 13 Ocak 2020'de tanımlanan bir virüstür. Başta Vuhan olmak üzere diğer şehirlere ve Çin Halk Cumhuriyeti'nin diğer eyaletlerine ve dünya ülkelerine yayılmıştır. Hastalığa yatkınlık için henüz net bir biyolojik işaret bulunmamaktadır. Yapılan açıklamalarda özellikle kronik hastalığı olanların ve 65 yaş üstü bireylerin taşıdıkları riske vurgu yapılmakla beraber süreç nedeniyle yaşanan kaygının dünya geneline yayıldığı söylenebilir. Ancak süreç herkesi aynı düzeyde etkilememekte ve bazı insanların daha fazla kaygılandıkları hatta panik yaptıkları görülmektedir. Zorlu yaşam olayları karşısında çeşitli stres tepkileri gösterilmesi, kaygı yaşanması beklendik bir durumdur. Salgın bağlamında düşünüldüğünde yaşanılan endişe bireyin kendisi ile sınırlı değildir. Birey kendisi kadar hatta bazen daha fazla, ailesi, sevdikleri için endişe duymakta ve kaygı, panik, korku gibi yoğun duygular yaşayabilmektedir. Hastalığa yakalanma riski altında olmak, virüs salgınının ne zaman son bulacağını tam olarak bilememek, salgın sürecinde yaşanabilecek sosyal ve ekonomik zorluklara yönelik belirsizlik yaşamak ve en önemlisi kendimizi ve ailemizi bu süreçte nasıl koruyacağımıza yönelik endişelerimiz ister istemez yoğun stres ve kaygı yaşamamıza neden olabilmektedir (MEB, 2020). Genel olarak tüm toplumu etkilemesine rağmen tepkilerinin şiddeti ve yoğunluğu kişiden kişiye değişiklik gösterebilmektedir. Süreci takip etmek gelişmeleri merak etmek olağan olmakla birlikte, internette saatlerce bu konuda araştırma yapmak, takıntılı bir șekilde sosyal medyayı, Tv haberlerini izlemek, vücudunu hastalık belirtileri açsından sik sik yoklamak gibi yineleyen davranışlar kaygı bozukluğunun belirtileri olarak değerlendirilebilir (Göka, Türkçapar, Sayar, Yavuz, Rashid, Dinç ve Çakır, 2020). Bu belirtilere iliş̧in sorular araştırmanın anketinde yer almaktadır. Araştırmada bireylerin psikolojik sağlamlık düzeyleri de incelenmektedir.

İnsanlar hem fiziksel özellikleri hemde duygu ve düşünceleri açısından birbirinden farklı özelliklere sahiptirler. $\mathrm{Bu}$ farklılıklar bireylerin davranışlarına da yansımakta ve farklı davranış profilleri çizmektedirler. Bazı insanlar hayatta karşılarına çıkan güçlükler karşı mücadele etmeden teslim olurken bazı insanlarsa sorunlarla daha etkili bir şekilde mücadele etme kapasitesine sahiptirler. Aynı olayı yaşayan insanlar farklı farklı tepki verebilmektedir. Kişilerin hayatları boyunca karşılaştıkları olumsuz yaşam olaylarında başa çıkma yeteneğini göstermesinde bireysel farklılıklar önemlidir (Gürgan, 2006). Bu insanların arasındaki farkın kaynağı çeşitli araştırmalara konu olmuş, özellikle insanın iyilik haliyle ilgilenen pozitif psikolojinin ilgi alanına girmiştir.

Pozitif psikoloji; kişilerin olumlu özelliklerinin geliştirilmesine ve nihayetinde psikolojik sağliklarının korunmasını odak alan bir disiplindir (Seligman ve Csikszentmihalyi, 2000). Pozitif psikolojinin üzerinde durduğu önemli kavramlardan biri psikolojik sağlamlıktır. "Psikolojik sağlamlık" kavramı latince resilience kelime kökünden türetilen esnek olma anlamında kullanılan elastikiyet anlamındadır (Hunter ve Chandler, 1999). Resilience sözcüğüne karşılık Türkçede farklı bazı kelimeler kullanılmaktadır. Bunlar: psikolojik sağlamlık (Gizir ve Aydın, 2006; Karaırmak, 2007); Yılmazlık (Ögülmüş, 2001; Özcan, 2005), kendini yeniden toparlayabilme yeteneği (Terzi, 2006) ve dayanıklılıktır (Taşğın ve Çetin, 2006). Bu araştırmada psikolojik sağlamlık kavramı kullanılmaktadır. Fraser, Richman ve Galinsky (1999) psikolojik sağlamlığı zorlu durumlarda bile pozitif kalma ve beklenmeyen durumlara kolay uyum sağlama becerisi olarak tanımlamaktadır. Ramirez (2007) ise hastalıklardan, olumsuz durumlardan, depresif duygu ve benzeri durumlardan sonra kolayca toparlayabilme, zorlayıcı yaşam olaylarından sonra eski haline gelebilme olarak tanımlamıştır. Psikolojik sağlamlıkla ilgili üzerinde uzlaşılmış bir tanım bulunmamakla birlikte psikolojik sağlamlık kavramının çeşitli riskler, koruyucu faktörler ve sonuçta ortaya çıkan uyum davranışı ile ilişkili olduğu görülmektedir (Gizir, 2007; Winders, 2014). Psikolojik sağlamlık kısaca olumsuz durumlar sonrasında bireyin gösterdiği uyum ve başa çıkma becerisi olarak tanımlanabilir (Block ve Kremen, 1996). Psikolojik sağlamlık kavramı her şey yolundayken ortaya çıkan ya da harekete geçen bir durum değildir. Bir yakının kaybı, ciddi bir hastalık ya da hastalık tehdidi, boşanma, doğal afetler gibi travmatik yaşantılar sonrası aktive olan bir süreç gibi düşünülebilir. Bu duruma salgın ve ölümcül bir virüs tehdidi de eklenebilir. Luthar, Cicchetti, ve Becker (2000) da psikolojik sağlamlığın söz konusu olması için iki ölçütten bahsetmektedirler.

Önemli bir tehdit ya da olumsuzluk durumuna maruz kalınması ve gelişim dönemlerini sekteye uğratacak önemli olumsuzluklara rağmen başarılı bir uyum sürecinin yaşanmasıdır. Literatüre 
bakıldığında buna benzer olarak psikolojik sağlamlık önemli risk veya travma yaşantılarına rağmen bireyin göstermiş olduğu olumlu uyumu ifade eden bir kavram olarak ele alınmaktadır (Luthar, Sawyer, ve Brown, 2006). Yapılan araştırmalar psikolojik sağlamlık düzeyleri iyi olan bireylerde anksiyete belirtilerinin daha az görüldüğü (Fredrickson, Tugade, Waugh ve Larkin, 2003) ve travmatik olaylar sonrasında da pozitif düşünebildikleri sonucuna ulaşılmıştır (Bonanno, Galea, Bucciarelli ve Vlahov, 2007). Covid 19 salgını sürecinde yaşanan hastalık korkusu da kaygıyı tetikleyici bir durum olarak kabul edilebilir. Bu araştırmanın amacı Covid 19 salgını sürecinde insanlar tarafından verilen ve kaygı bozukluğu belirtisi olarak kabul edilebilecek bazı tepkilerin hem bireylerin sahip oldukları psikolojik sağlamlık düzeyi hemde bazı değişkenler açısından incelenmesidir.

\section{YÖNTEM}

\section{Araştırma Deseni}

$\mathrm{Bu}$ çalışma betimsel tarama yönteminde kesitsel model kullanılarak yürütülmüştür. $\mathrm{Bu}$ yöntem katılımcıların görüşlerinin ya da ilgi, beceri, yetenek, tutum gibi özelliklerinin belirlenmesine olanak sağlamaktadır $\mathrm{Bu}$ yöntemde araştırmacılar elde etmek istedikleri verileri örneklemden kısa bir süre içerisinde toplayabilmekte ve bu yöntemi tercih eden araştırmacılar büyük sayıda örneklemler üzerinde çalışmalar yürütebilmektedirler (Fraenkel, Wallen ve Hyun, 2012).

\section{Çalışma Grubu}

Araştırmanın verileri Karadeniz bölgesinden basit örnekleme yöntemi kullanılarak elde edilmiştir. Araştırma için Gümüşhane Üniversitesi Bilimsel Araştırma ve Yayın Etiği kurulundan onay alınmıştır (08/07/2020 tarih ve 2020/7 sayılı yazı). Katılımcıların büyük çoğunluğu şehir merkezlerinde yaşamaktadır. 332 kadın 167 erkek olmak üzere toplam 499 kişiden oluşan çalışma grubuna 18 yaş ve üstü bireyler dahil edilmiştir. Araştırmanın verileri gönüllülük esasına göre google formlar üzerinden 2020 Mart ve Nisan ayları içerisinde toplanmıştır.

Tablo 1. Araştırmanın çalışma grubuna ilişkin bilgiler

\begin{tabular}{cccc}
\hline \multirow{2}{*}{ Cinsiyet } & & $\mathrm{f}$ & $\%$ \\
\cline { 2 - 4 } & Kadın & 332 & 66,5 \\
\cline { 2 - 4 } Medeni Durum & Erkek & 167 & 33,5 \\
\cline { 2 - 4 } & Bekar & 296 & 59,3 \\
\cline { 2 - 4 } & Evli & 203 & 40,7 \\
\cline { 2 - 4 } & Düşük & 20 & 4,0 \\
\cline { 2 - 4 } Ekonomik Durum & Orta & 260 & 52,1 \\
\cline { 2 - 4 } & İyi & 202 & 40,5 \\
\cline { 2 - 4 } & Çok iyi & 17 & 3,4 \\
\cline { 2 - 4 } & Total & 499 & 100,0 \\
\hline
\end{tabular}

\section{Veri Toplama Araçları}

\section{Kısa Psikolojik Sağlamıı Ölçeği (KPSÖ)}

Araştırmada veri toplama aracı olarak Smith, Dalen, Wiggins, Tooley, Christopher, ve Bernard, (2008) tarafından geliştirilen ve Doğan, (2015) tarafından Türkçe uyarlaması yapılan Kısa Psikolojik Sağlamlık Ölçeği kullanılmıştır. Beşli likert tipindeki ölçekte altı madde bulunmaktadır. Öz bildirim tarzı bir ölçek olan KPSÖ'de 2, 4 ve 6. maddeler tersten puanlanmaktadır. Ölçekten alınan yüksek puan yüksek psikolojik sağlamlık düzeyine işaret etmektedir. Doğan (2015) tarafından yapılan uyarlama çalışmasında KPSÖ'ye ilişkin iç tutarlık katsayısı .83; bu araştırmada ise .78 olarak bulunmuştur. 


\section{Kişisel bilgi formu}

Araştırmacı tarafından hazırlanan kişisel bilgi formu, çalışma grubunun demografik bilgilerini (cinsiyet, yaş, medeni durum, eğitim düzeyi, kronik bir hastalığı bulunup bulunmadığı) içeren sorulardan oluşmaktadır.

\section{Anket}

Araştırmacı tarafından hazırlanan ankette mevcut pandemi sürecinde kayg1 göstergesi olarak kabul edilebilecek davranışlara ilişkin ifadeler yer almaktadır. Anket, araştırma öncesinde 60 kişilik bir gruba uygulanmış ve Cronbach Alpha değeri .70 in altında olan ifadeler anketten çıkartılarak ankete son hali verilmiştir. Araştırmada kullanılan anketin son halinde 6 ifade yer almaktadır ve Cronbach Alfa değeri .76 'dır.

\section{Verilerin Toplanması}

Kullanılan ölçek için izin alındıktan sonra veriler 2020 yılı Mart ve Nisan aylarında online olarak toplanmıştır. Toplam 596 kişiye iletilen ölçekten 512 adet cevaplanmış olarak geri dönmüş, eksik doldurulan 13 anket iptal edildikten sonra 499 kişilik bir veri seti oluşturulmuştur.

\section{Veri analizi}

Elde edilen veriler SPSS 24 programında analiz edilmiştir. Analizler öncesinde verilerin normal dağılım gösterip göstermedikleri belirlenmiş ve seçilecek analizlere karar verilmiştir. Ankete verilen cevapların yüzde ve frekansları belirlenmiştir. Ankete verilen cevapların demografik değiş̧kenlere göre farklılaşma durumlar Ki-Kare testi ile hesaplanmıştır. Psikolojik sağlamlık düzeyinin cinsiyet açısından farkılaşıp farklılaşmadığını belirlemek amacıyla t-testi; anket maddelerine verilen cevapların psikolojik sağlamlık açısından incelenmesinde iki kategorli olanlarda t-testi; 3 ve daha fazla olanlarda ANOVA testi kullanılmıştır. ANOVA testinde farkın kaynağını belirlemek amacıyla Bonferoni testi kullanılmıştır.

\section{BULGULAR}

Araştırmanın bu bölümünde çalışma grubundan elde edilen verilerin analizlerinden elde edilen sonuçlar yer almaktadır.

Tablo 2. Ankete verilen cevapların dağllımların gösteren tablo

\begin{tabular}{|c|c|c|c|c|c|}
\hline & & & $\mathrm{f}$ & $\%$ & $\begin{array}{c}\text { Cinsiyete göre } \\
\text { farklılaşma durumu }\end{array}$ \\
\hline & \multirow{2}{*}{$\begin{array}{l}\text { Covid } 19 \text { (Korona) ile ilgili haberleri her akşam } \\
\text { izlerim }\end{array}$} & Evet & 371 & 74.35 & \multirow{2}{*}{$\chi 2=.001 ; \mathrm{sd}: 1 \mathrm{p}=.97$} \\
\hline & & Hayır & 128 & 25.65 & \\
\hline \multirow{3}{*}{\multicolumn{2}{|c|}{ 2. Vaka sayılarını günlük olarak takip ederim }} & Evet & 359 & 71.94 & \multirow{3}{*}{$\chi 2=1.466 ; \mathrm{sd}: 2 \mathrm{p}=.48$} \\
\hline & & Hayır & 38 & 7.62 & \\
\hline & & Bazen & 102 & 20.44 & \\
\hline & \multirow{2}{*}{$\begin{array}{l}\text { Covid } 19 \text { nedeniyle sağlık bakanlığının sosyal } \\
\text { medya hesaplarını takip etmeye başladım }\end{array}$} & Evet & 245 & 49.10 & \multirow{2}{*}{$\chi 2=7.052 ; \mathrm{sd}: 1 \mathrm{p}=.00$} \\
\hline & & Hayır & 254 & 50.90 & \\
\hline \multirow{2}{*}{\multicolumn{2}{|c|}{$\begin{array}{l}\text { 4. Covid } 19 \text { nedeniyle maske / eldiven / dezenfektan } \\
\text { satın aldım }\end{array}$}} & Evet & 395 & 79.16 & \multirow{2}{*}{$\chi 2=10.991 ; \mathrm{sd}: 1 \mathrm{p}=.00$} \\
\hline & & Hayır & 104 & 20.84 & \\
\hline \multirow{3}{*}{\multicolumn{2}{|c|}{$\begin{array}{l}\text { 5. Bu salgından duyduğum kaygı nedeniyle uyku } \\
\text { düzenim bozuldu }\end{array}$}} & Evet & 71 & 24.23 & \multirow{3}{*}{$\chi 2=7.418 ; \mathrm{sd}: 2 \mathrm{p}=.02$} \\
\hline & & Hayır & 308 & 51.72 & \\
\hline & & Kismen & 120 & 24.05 & \\
\hline \multirow{3}{*}{\multicolumn{2}{|c|}{$\begin{array}{l}\text { 6. Zaman zaman kendimi Covid } 19 \text { belirtisi gösteriyor } \\
\text { muyum diye incelerken buluyorum }\end{array}$}} & Evet & 141 & 28.3 & \multirow{3}{*}{$\chi 2=8.501 ; \mathrm{sd}: 2 \mathrm{p}=.01$} \\
\hline & & Hayır & 183 & 36.7 & \\
\hline & & Bazen & 175 & 35.1 & \\
\hline
\end{tabular}

Tablo'2 ye bakıldığında anketin birinci maddesine çalışma grubunda yer alan bireylerin \%74.3 gibi çok büyük bir çoğunluğunun evet dedikleri görülmektedir. Başka bir deyişle $\% 74.3$ gibi büyük bir çoğunluk Covid 19 ile ilgili haberleri günlük olarak takip etmektedir. Bu durumun cinsiyet, medeni durum, eğitim 
düzeyi ve algılanan ekonomik durum açısından farklılaşıp farklılaşmadığına ilişkin yapılan analizler sonucunda aralarında anlamlı bir fark olmadığı bulgulanmıștır. Anketin ikinci maddesine ilişkin bulgulara göre çalışma grubunda yer alan bireylerin \%71.9 gibi çok büyük bir çoğunluğunun vaka sayılarını günlük olarak takip ettikleri görülmektedir. Katılımcıların \%20.4 ü bazen izlediğini, \%7.6 sı da takip etmediğini ifade etmiştir. Bu durumun cinsiyet, medeni durum, eğitim düzeyi ve algılanan ekonomik durum açısından farklılaşıp farklılaşmadığına ilişkin yapılan analizler sonucunda aralarında anlamlı bir fark olmadığı bulgulanmıştır. Anketin 3. Maddesi olan sağlık bakanlığının sosyal medya hesaplarının takibi ile ilgili olarak çalışma grubunun \% 50.9 unun Sağlık bakanlığının sosyal medya hesaplarını takip etmeye başladığını göstermektedir. Bu durumun cinsiyet, medeni durum, eğitim düzeyi ve algılanan ekonomik durum açısından farklılaşıp farklılaşmadığına ilişkin yapılan analizler sonucunda cinsiyet açısından farklılaşmalar olduğu görülmüştür. Kadınların oranı erkelerin oranından anlamlı olarak yüksektir. $(\chi 2=7.052 ; \mathrm{sd}: 1 ; \mathrm{p}=.00)$. Anketin 4 . Maddesinde yer alan maske eldiven ve dezenfektan alınması ile ilgili olarak çalışma grubunda yer alan bireylerin \% 79.2 sinin salgın haberleri sonrasında maske eldiven dezenfektan aldıklarını ifade ettikleri görülmektedir. $\mathrm{Bu}$ durumun cinsiyet, medeni durum, eğitim düzeyi ve algılanan ekonomik durum açısından farklılaşıp farklılaşmadığına ilişkin yapılan analizler sonucunda cinsiyet açısından farklılaşmalar olduğu görülmüştür. Kadınların oranı erkelerin oranından anlamlı olarak yüksektir. $(\chi 2=10.991 ; \mathrm{sd}: 1 ; \mathrm{p}=.00)$. Anketin 5. Maddesinde yer alan salgın nedeniyle uyku düzenim bozuldu maddesine çalışma grubunda yer alan bireylerin \%24.2 sinin evet dediği, \%24 nün ise kısmen maddesini işaretledikleri, \% 51.7 sinin ise hayır seçeneğini işaretledikleri görülmektedir. Bir başka deyişle katılımcıların \%48 nin uyku düzeninin bu süreçten etkilendiği söylenebilir. $\mathrm{Bu}$ durumun cinsiyet, medeni durum, eğitim düzeyi ve algilanan ekonomik durum açısından farklılaşıp farklılaşmadığına ilişkin yapılan analizler sonucunda cinsiyet açısından farklılaşmalar olduğu görülmüsştür. Kadınların oranı erkeklerin oranından anlamlı olarak yüksektir. $(\chi 2=7.418$; sd: $2 ; p=.02)$. Yani kadın katılımcıların uyku düzeni bu süreçten daha fazla etkilenmiştir denilebilir. Anketin 6. Maddesinde yer alan zaman zaman kendimi Covid 19 belirtisi gösteriyor muyum maddesine, çalışma grubunda yer alan bireylerin \% 28.3 nün evet, \% 35.1 lik bir bölümün ise bazen, \%36,7 lik bir kısımın ise hayır dedikleri belirlenmiştir. Katılımcıların yaklaşık \%58 lik bir bölümü belirtiler açısından kendisini kontrol etmektedir. Bu durumun cinsiyet, medeni durum, eğitim düzeyi ve algılanan ekonomik durum açısından farklılaşıp farklılaşmadığına ilişkin yapılan analizler sonucunda cinsiyet açısından farklılaşmalar olduğu görülmüştür. Kadınların oranı erkeklerin oranından anlamlı olarak yüksektir $(\chi 2=8.501 ; \mathrm{sd}: 2 ; \mathrm{p}=.01)$.

Sonuçlara bakıldığında Covid 19 salgınının bireylerin yaşam düzenini olumsuz yönde etkilediği söylenebilir. Bireylerin kaygı nedeni ile korona ile ilgili haberleri sürekli izledikleri, vaka sayılarını ve sosyal medya hesaplarını takip ettikleri, önleyici tedbirler konusunda hassasiyet geliştirdikleri, tüm bu süreç nedeniyle uyku düzenlerinin bozulduğu ve semptomlar açısından kendilerini sık sık kontrol ettikleri görülmektedir. Bu durumların bazılarının demografik değişkenler açısından farklılık gösterdiği ve genel olarak kadınların bu süreçte erkeklerden daha fazla etkilendikleri söylenebilir. Ayrıca semptomlar açısından kendi kontrol etme davranışlarına evlilerde bekarlara göre daha fazla rastlanıldığı söylenebilir. Kadınların duygusal anlamda daha duyarlı olmaları ve duyguları daha yoğun yaşamaları bu durumun sebebi olarak düşünülebilir. Bu araştırmada incelenen psikolojik sağlamlık düzeyi de bu durumun nedenlerinden biri olarak kabuk edilebilir. Kadınların psikolojik sağlamlık düzeyleri erkeklere göre daha düşüktür ve aralarındaki fark anlamlıdır. Bütün anket maddeleri psikolojik sağlamlık ölçeği sonuçları açısından karşılaştırılmış anlamlı çıkan sonuçlar Bu sonuca ilişkin bulgular tablo 3'te yer almaktadır.

Tablo 3. Psikolojik sağlamlık düzeyinin cinsiyet değişkeni açısından incelenmesi

\begin{tabular}{cccccc} 
& $\mathrm{n}$ & Ort. & Ss & $\mathrm{t}$ & $\mathrm{p}$ \\
\hline Kadın & 332 & 19.23 & 4.53 & & \\
Erkek & 167 & 20.51 & 3.87 & 3.12 & .00
\end{tabular}


Tablo 3'e bakıldığında yapılan t-testi sonucunda kadın ve erkekler arasında psikolojik sağlamlık düzeyi açısından anlamlı $(\mathrm{p}<.01)$ farklılıklar olduğu görülmektedir. Erkeklerin psikolojik sağlamlık düzeyleri kadınlardan daha yüksek olarak bulunmuştur. Bu durumun kadınların daha duygusal olmaları, olaylara sonuç değil süreç odaklı yaklaşmaları ile ilgili olduğu söylenebilir. Erkeklerin daha iyimser olduklarına ilişkin araştırma bulguları olduğu bilinmektedir ve iyimserlik de psikolojik sağlamlığın bir bileşeni olarak kabul edilmektedir.

Tablo 4. Bu salgindan duyduğum kaygı nedeniyle uyku düzenim bozuldu ifadesine verilen cevapların psikolojik sağlamlık düzeyleri açısından incelenmesi

\begin{tabular}{|c|c|c|c|c|c|}
\hline & KT & Sd & KO & F & p \\
\cline { 1 - 4 } Gruplararas1 & 390.192 & 2 & 195.096 & & \multirow{2}{*}{10.655} \\
\cline { 1 - 3 } Grup içi & 9082.208 & 496 & 18.311 & .00 \\
\cline { 1 - 3 } Toplam & 9472.401 & 498 & & & \\
\hline
\end{tabular}

Yapılan ANOVA analizi sonucunda anketin 5. Maddesine verilen cevapların psikolojik sağlamlık açısından farklılaştığı bulgulanmıştır. Farkın kaynağını belirlemek amacıyla yapılan Bonferroni analizi sonucunda farkın kaynağı ifadeye evet cevabı verenlerin psikolojik sağlamlık puan ortalamalarının hayır ve bazen diyenlerden daha düşük olmasıdır $\left(\mathrm{F}_{(2-496)}=10.655 ; \mathrm{p}<.01\right)$. Başka bir deyişle salgından duyduğu kaygı nedeniyle uyku düzeni bozulan bireylerin psikolojik sağlamlık düzeylerinin bu sorunu bazen yaşayanlardan ve hiç yaşamayanlardan daha düşük olduğu saptanmıştır. Kaygı ve bezer duyguların beslenme alışkanlıkları, uyku düzeni üzerinde bozucu etkinlerinin olduğu bilinmektedir. Covid 19 nedeniyle yaşanan kaygının da bu sonucu doğurması beklenen bir durumdur. Psikolojik sağlamlık zorlayıcı yaşam olaylarına karşı daha esnek olabilmeyi kolaylaştırıcı bir faktördür. Psikolojik sağlamlık birden çok bileşeni içeren bir sistemdir bu bunların içinde olumlu başa çıkma becerisi de yer almaktadır bu aynı zamanda koruyucu bir faktör olarak ifade edilmektedir (Secades, 2016) Tüm bunların 1şığında psikolojik sağlamlık düzeyi yüksek bireylerin bu süreçle daha etkin başa çıkması, mevcut duruma esneyebilme kapasitesi sayesinde daha kolay uyum sağlaması ve daha az zarar görmesi beklenen bir durumdur. Psikolojik sağlamlık, bireyin risk durumunun getirdiği olumsuzluklar karşısında uyum sağlaması ve olumlu sonuçlara ulaşabilmesidir.

Tablo 5. "Zaman zaman kendimi Covid 19 belirtisi gösteriyor muyum diye incelerken buluyorum" ifadesine verilen cevapların psikolojik sağlamlık düzeyleri açısından incelenmesi

\begin{tabular}{cccccc} 
& KT & Sd & KO & F & p \\
\hline Gruplararas1 & 324.361 & 2 & 162.180 & & \\
Grup içi & 9148.040 & 496 & 18.444 & 8.793 & .00 \\
Toplam & 9472.401 & 498 & & &
\end{tabular}

Yapılan ANOVA analizi sonucunda anketin 6. Maddesine ilişkin cevapların psikolojik sağlamlık açısından anlamlı olarak farklılaştığı $(\mathrm{p}<.01)$ görülmüştür. Farkın kaynağını belirlemek amacıyla yapılan Bonferroni analizi sonucunda farkın kaynağı maddeye evet cevabı verenlerin psikolojik sağlamlık puan ortalamalarının hayır diyenlerden daha düşük olmasıdır $\left(\mathrm{F}_{(2-496)}=8.793 ; \mathrm{p}<.01\right)$ Başka bir deyişle kendini Covid 19 belirtisi gösteriyor muyum diye sık sık kontrol eden insanların psikolojik sağlamlık düzeylerinin bu ifadeye hayır ve bazen diye cevap verenlerden daha düşük olduğu saptanmıştır. Psikolojik sağlamlık kriz durumlarıyla aktif olarak bahşedebilme, negatif duygusal tecrübeler, değişen istekler ile stresli yaşam tecrübelerine karşı esneklik olarak tanımlanmaktadır 
(Tugade ve Fredrickson, 2004). Hastalık ve ölüm kaygısının yoğun yaşandığı bu dönemde bu duygularla başedebilmede psikolojik sağlamlığın süreci kolaylaştırıcı bir rolü olduğu söylenebilir.

\section{TARTIŞMA, SONUÇ VE ÖNERILER}

Araştırma sonuçlarına bakıldığında katılımcıların yaklaşık \%74 lük gibi büyük bir çoğunluğunun Covid 19 ile ilgili haberleri düzenli olarak takip ettiğini, buna yakın bir oran ile (\%71) vaka sayılarını günlük olarak takip ettiğini ifade ettikleri görülmektedir. Çalışma grubunun \%49'u sağlık bakanlığının sosyal medya hesapları takip etmeye başladığını ifade ettikleri görülmüştür. Tüm bu davranışların bir sağlık kaygısının uzantısı olduğu söylenebilir (Göka vd. 2020). Hastalığın gidişatı ile bilgi sahibi olunmak istenmesi normal kabul edilebilirken saplantılı bir şekilde araştırma yapılması, her haberin izlenmesi bu durumun bir kaygı bozukluğu olarak yorumlanmaya müsait hale getirmektedir. $\mathrm{Bu}$ ifadeler verilen cevapların psikolojik sağlamlık açısından farkılaşıp farklılaşmadıklarını belirlemek amacıyla analizler yapılmış ve anlamlı bir farklılık olmadığı belirlenmiştir.

Çalışma grubunda yer alan bireylerin \% 79 gibi çok büyük bir bölümü salgın sürecinde maske- eldivendezenfektan aldıklarını ifade etmişlerdir. Bu maddeye verilen cevapların cinsiyete göre farklılaştığı ve kadınların bu davranışları daha fazla gösterdikleri belirlenmiştir. Bu sonuç hijyen konusunda kadınların genel anlamda daha hassas olmaları ile ilişkilendirilebilir. Katılımcıların \%24'ü yaşadıkları kaygı nedeniyle uyku düzenlerinin bozulduğunu, \% 24 ise kısmen bozulduğunu ifade etmektedir, yani yaklaşık olarak katılımcıların yarısının uyku düzenleri bu süreçten olumsuz etkilenmiştir denilebilir. Bu ifadeye verilen cevaplarda cinsiyet değişkeni açısından farklılaştığı bulgulanmıştır ve kadınların bu sorunu daha fazla yaşadıkları belirlenmiştir. Katılımcıların \% 28 i kendilerini zaman zaman Covid 19 belirtileri açsından yokladığını, \% 35'i ise bunu zaman zaman yaptıklarını ifade etmiştir. Bu oran da katılımcıların yaklaşık \% 63 ne denk gelmektedir. Tüm bu sonuçlara bakılarak Covid 19 salgının insanların yaşam düzenlerini olumsuz etkilediği, belirsizlik duygusuna yol açtığını ve kaygı düzeylerini yükselttiği söylenebilir.

Hastalığa yakalanmamak için alınan tedbirlerin insanların tüm alışkanlıklarını değiştirdiği, günlük rutinlerde aksalığa yol açtığı düşünüldüğ̈̈nde bu beklenen bir sonuçtur. Ankete verilen cevapların psikolojik sağlamlık açısından yapılan değerlendirmesi sonucunda "Kendimi Covid 19 belirtisi gösteriyor muyum diye incelerken buluyorum" ifadesi ile "Bu salgından duyduğum kaygı nedeniyle uyku düzenim bozuldu ifadesine" verilen cevapların farklılaştığı ve psikolojik sağlamlık düzeyi düşük olanların bu durumu daha yoğun yaşadığ 1 ve aralarındaki farkın anlamlı olduğu bulunmuştur. Literatürde bu sonucu doğrulayan bilgiler bulunmaktadır. Psikolojik sağlamlığı yüksek olan bireylerin stresli yaşam olayları karşısında duygusal veya fiziksel bozukluk yaşamayan (Sipahioğlu, 2008) yaşasalarda eski hallerine geri gelmeleri ve devam etmelerini sağlayan bir bakış açısına sahip oldukları bildirilmektedir (Parr, Montgomery ve DeBell, 1998). Psikolojik sağlamlık düzeyleri iyi olan bireylerde anksiyete belirtilerine daha az rastlandığı (Fredrickson, Tugade, Waugh ve Larkin, 2003) ve travmamatik yaşantılarda bile pozitif bakabildikleri sonucuna ulaşan araştıma sonuçları vardır (Bonanno, Galea, Bucciarelli ve Vlahov, 2007). Alfred ve Smith, 1999 yaptıkları araştırmada psikolojik sağlamlık düzeyi iyi olan kişilerin kendileri için tehdit sayılan durumlar karşısında daha sakin kaldıkları ve tepkilerinin daha olumlu sonucuna ulaşmıştırlar. Alanyazında ele alınan risk durumlarına örnek olarak savaş ve travma (Hubbard, Realmuto, Northwood, ve Masten, 1995; psikolojik problemli ebeveynler; (Beardslee ve Podorefsky, 1988), AIDS (Rabkin, Remien, Katoff, ve Williams, 1993) ve kanser (Antoni ve Goodkin, 1988; Özçetin-Üzar ve Hiçdurmaz, 2017) verilebilir. Psikolojik sağlamlık düzeyi düşük olanların uyku düzenlerinin daha fazla etkilendiği bulgusu alanyazında ki araştırma sonuçları ile de tutarlıdır. Psikolojik sağlamlık ile iyi uyku arasında pozitif ve anlamlı ilişki olduğunu sonucuna ulaşan araştırmalar olduğu görülmektedir (Öztürk, 2019). Psikolojik sağlamlık düzeyi düşük olan bireylerin bu süreçte daha yoğun kaygı yaşadıkları ve bu durumun günlük yaşamlarını daha olumsuz etkiledikleri söylenebilir. Davydov, Stewart, Ritchie ve Chaudieu, (2010) sorunların çözümünde güçlük veya stres gibi istenmeyen deneyimlerin zayıf psikolojik sağlamlık düzeyi ile ilişkili olduğunu ifade etmektedirler. Yüksek kaygı ve stresin uyku üzerinde olumsuz etkileri olduğu bilinmektedir. Araştırma bulgularımız kadınların daha fazla uyku problem yaşadığını göstermketedir bu durumun kadınların psikolojik sağlamlık düzeylerinin erkeklerden daha düşük düzeyde bulunmuş olması ile ilişkili olduğu düşünülmektedir. Literatüre bakıldığında cinsiyet açısından farklı sonuçlar olduğu görülmektedir. $\mathrm{Bu}$ 
araştırma benzer sonuçlara ulaşarak erkeklerin psikolojik sağlamlık düzeylerinin daha yüksek olduğu sonucuna ulaşan araştırma sonuçları olduğu gibi (Açıkgöz, 2016; Bahadır, 2009; Clark ,1995; Sezgin, 2016); kadınların psikolojik sağlamlık düzeylerinin daha yüksek olduğunu bulgulayan araştırma sonuçları da vardır (Kılıç (2014; Oktan, Odacı ve Berber-Çelik 2014; Oktan, 2008). Anlamlı fark bulan araştırmaların yanı sıra psikolojik sağlamlığın cinsiyete göre farkılaşmadığı bulgusuna ulaşan araştırma sonuçları olduğu da görülmektedir (Akça ,2012; Aydın ve Egemberdiyeva, 2018; Aydın, 2010; Aydoğdu ,2013; Bolat 2013; Dursun ve Özkan, 2019; Özer, 2013; Terzi ,2008). Bu süreçte psikolojik sağlamlık düzeyleri yüksek olan bireylerin süreci daha az psikolojik hasarla atlatacakları söylenebilir. Bulut (2016) da psikolojik sağlamlık düzeyleri yüksek olan bireylerin stres verici olaylarla baş edebildiklerini ve zorlu yaşam olaylarına daha kolay uyum sağlayabildiklerini ifade etmektedir. İnsanlar genel anlamda kendilerini güvende hissetmek ve olayların kontrol altında olduğunu bilme ihtiyacı hissetmektedirler. Salgın hastalık sürecinde bu ihtiyaç karşılanamadığı içinde organizma alarm duruma geçmekte, kaygı sirenleri çalmakta ve vucüt stres tepkileri geliştirebilmektedir. Yaşanan bu riskli sürecin devam ediyor olması olumsuz psikolojik etkileri konusunda riskin devam ettiği anlamında gelmektedir.

Tüm durumlarla baş etmede bireye kolaylaştırıcı etki yapan psikolojik sağlamlık düzeyini yükseltecek çalışmaların yapılması büyük önem arz etmektedir. Psikolojik sağlamlıkla ilgili yapılan araştırmalar bazı kişilik özelliklerinin Özsaygı (Dumont ve Provost, 1999), yaşam doyumu (Fredrickson, Tugade, Waugh ve Larkin, 2003), olumlu duygusallık (Tugade ve Frederickson, 2004) ve iyimserlik (Kumpfer, 1999) ve duygusal zeka (Armstrong ve Galligan, 2011; Bumphus, 2008; Özer ve Deniz, 2014; Sandel, 2007) psikolojik sağlamlıkla ilişkili olduğunu göstermektedir. Bu özelliklerin bazıları geliştirilebilir özelliktedir ve bunlara yönelik iyileştirici çalışmalar bireylerin psikolojik sağlamlık düzeylerini de olumlu yönde etkileyeceği söylenebilir. Örneğin duygusal zekâ ile ilgili yapılacak etkinliklerin psikolojik sağlamlık üzerinde olumlu etkileri olacağı söylenebilir. Bu konuda araştırma yapacak olan araştırmacıların psikolojik sağlamlık üzerinde etkili olacak değişkenlere yönelik deneysel araştırmalara yapmalarının alana katkı yapacağı söylenebilir. Ayrıca salgın sonrasında bireylerin süreçten nasıl etkilendikleri üzerine yapılacak araştırmalarında sürecin bireyler üzerindeki etkilerini anlamaya katkı sağlayacağı söylenebilir. Covid 19 sürecinde ihtiyaç duyan bireylere çeşitli kurumlar aracılılığı ile online danışmanlık hizmeti verilmesi yaşanan sorunların derinleşmesini önleyecektirir. Bireylerin bu süreçte kaygıları ile başedebilmeleri ve psikolojik sağlamlık düzeylerini artırmak için aşağıda yer alan hususlara dikkat etmeleri önerilmektedir.

- Güvenilir bilgi kaynaklarından edinilen bilgiler doğrultusunda gerekli tedbir davranışlarını belirlemek ve bunlarda istikrarlı olmak. Bu durum kontorl duygusunun güçlenmesine katkı yapacaktır.

- Sürekli salgın ile ilgili programları izlemekten ve bilgi kirliliğinden kaçınmak.

- Olabildiğince olumlu düşünmek, riski kabul etmek ancak gerekli tedbirleri alarak süreci sağlıklı atlatabileceğine ilişkin inancını beslemek ve temeli hayatta kalma motivasyonuna dayanan kaygının varoluş amacına hizmet etmesini sağlamak.

- Kaygının normal olduğunu kabul etmek ve bununla başetme becerilerini geliştirmek.

- Fiziksel izolasyonu sosyal izolasyona dönüştürmemeye özen göstererek bireylerin arkadaşları ve dostlarıyla iletişimi sürdürmesi ve salgın dışındaki konulardan konuşması normalleşme sürecini hızlandırıcı bir tutum olacaktır.

- Ev içersinde birlikte keyif alınabilecek etkinlikler yapılması (egzersiz yapmak, puzzle yapmak; dijital oyunlar oynamak vb) dikkatin kaygıdan başka şeylere yönelmesine katkı sağlayacaktır.

- Mizahın iyileştirici gücünden yararlanmak ve komedi filmleri izlemek

- Enerjinin kontrol edilemeyecek şeylerden kontrol edilebilecek alanlara yöneltilmesi bireyin kontrol algısını yükseltecektir. (Yeme-içme düzeni, uyku düzeni çalışma düzeni gibi)

- Kaygı sürecinde işe yarayacak gevşeme ve nefes egzersizlerine zaman ayırılması. 
Bilgilendirme / Acknowledgement:

1-Araştırma için Gümüşhane Üniversitesi Bilimsel Araştırma ve Yayın Etiği Kurulundan 08/07/2020 tarih ve 2020/7 sayısı ile onay alınmıştır.

2. Bu makalede araştırma ve yayın etiğine uyulmuştur.

\section{KAYNAKÇA}

Açıkgöz, M. (2016). Çukurova Üniversitesi Tıp Fakültesi öğrencilerinin psikolojik sağlamlık ile mizah tarzları ve mutluluk düzeyleri arasındaki ilişkinin incelenmesi. Yayınlanmamış yüksek lisans tezi, Çağ Üniversitesi, Mersin.

Akça, Z.K. (2012). Genç yetişkinlikte algılanan anne-baba tutumlarının, kendini toparlama gücü ve benlik saygısı arasındaki ilişsi. Yayınlanmamış yüksek lisans tezi, Maltepe Üniversitesi, İstanbul.

Antoni, M.H. ve Goodkin, K. (1988). Host moderator variables in the promotion of cervical neoplasia_I. Personal facests. Journal of Psychosomatic Research, 32, 3, 327-338

Armstrong, A. and Galligan, R. (2011). Eq and psychological resilience to negative life events. Personality and Individual Differences, 51, 331-336

Aydın, B. (2010). Üniversite ögrencilerinin duygusal zeka ve umut düzeyleri ile psikolojik sağlamlıkları arasındaki ilişkinin incelenmesi. Yayımlanmamış yüksek lisans tezi, Karadeniz Teknik Üniversitesi, Trabzon.

Aydın, M. ve Egemberdiyeva, E. (2018). Üniversite öğrencilerinin psikolojik sağlamlık düzeylerinin incelenmesi. Türkiye Eğitim Dergisi, 3(1), 37-53.

Aydoğdu, T. (2013). Bağlanma stilleri, başa çıma stratejileri ile psikolojik dayanıklılık arasındaki ilişkinin incelenmesi. Yayınlanmamıș yüksek lisans tezi, Gazi Üniversitesi, Ankara.

Bahadır, E. (2009). Sağlıkla ilgili fakülteler de eğitime başlayan öğrencilerin psikolojik sağlamlık düzeyleri. Yayımlanmamış yüksek lisans tezi, Hacettepe Üniversitesi, Ankara.

Beardslee,W. R. ve Podorefsky D. (1988). Resilient adolescents whose parents have serious affective and other psychiatric disorders: Importance of selfunderstanding and relationships. American Journal of Psychiatry, 145(1), 63-69.

Block, J. ve Kremen, A. M. (1996). IQ and ego resiliency: Conceptual and empirical connections and separateness. Journal of Personality and Social Psychology, 70(2), 349-361.

Bolat, Z. (2013). Üniversite ögrrencilerinin psikolojik sağlamlık ve öz-anlayışları arasındaki ilişkinin incelenmesi. Yayınlanmamış yüksek lisans tezi, Necmettin Erbakan Üniversitesi, Konya.

Bonanno, G. A., Galea, S., Bucciarelli, A. \& Vlahov, D. (2007). What predicts psychological resilience after disaster? the role of demographics, resources and life stres. Journal of Consulting and Clinical Psychology, 75(5), 671-682.

Bulut, B. (2016). Ergenlerin anksiyete, sosyal destek ve psikolojik sağlamlık düzeyleri arasındaki ilişkilerin incelenmesi. Yayınlanmamış yüksek lisans tezi, Atatürk Üniversitesi, Erzurum.

Bumphus, A.T. (2008). The emotional intelligence and resilience of school leaders: an investigation into leadership behaviours. Yayımlanmamıs doktora tezi, The University of Southern Missisipi, ABD.

Clark, P. (1995). Risk and resiliency in adolescence: The current status of research of gender differences. Equity Issues, 1(1), 1-13. 
Davydov, DM., Stewart, R., Ritchie, K., Chaudieu, I. (2010). Resilience and mental health. Clinical Psychology Review, 30, 479-495.

Doğan, T. (2015). Kısa psikolojik sağlamlık ölçeği’nin türkçe uyarlaması: geçerlik ve güvenirlik çalışması. The Journal of Happiness \& Well-Being, 3(1), 93-102.

Dumont, M. ve Provost, M. A. (1999). Resilience in adolescents: Protective role of social support, coping strategies, self-esteem and social activities on experience of stress and depression. Journal of Youth and Adolescence, 28(3), 343-363.

Dursun, A. Ve Özkan, M.S.(2019). Ergenlerin gelecek kaygıları ile psikolojik sağlamlıkları arasındaki ilişkide yaşam doyumunun aracı rolü. Yaşam Becerileri Dergisi, 3(5), 23-37.

Fraenkel,, J. R., Wallen, N. E. and Hyun, H. H. (2012). How to design and evaluate research in education (8th ed.). New York, NY: Mc Graw Hilln Education.

Fraser, M.W., Galinsky, M.J., \& Richman, J.M. (1999). Risk, protection, and resilience: Toward a conceptual framework for social work practice. Social Work Research, 23(3), 131-143.

Fredrickson, B. L., Tugade, M. M., Waugh, C. E. ve Larkin, G. R. (2003). What good are positive emotions in criese? A prospective study of resilience and emotions following the terrorist attacks on the United States on September 11th, 2001. Journal of Personality and Social Psychology, 84(2), 365-376

Gizir, C. A. (2007). Psikolojik sağlamlık, risk faktörleri ve koruyucu faktörler üzerinde bir derleme çalışması. Türk Psikolojik Danışma ve Rehberlik Dergisi, 3, 28, 113-128.

Gizir, C. A. ve Aydın, G. (2006) Psikolojik sağlamlık ve ergen gelişim ölçeğinin uyarlanması: Geçerlik ve güvenirlik çalışmaları. Türk PDR Dergisi, 3(26), 87-99

Gürgan, U. (2006a). Yılmazlık Ölçeği (YÖ): Ölçek geliştirme, güvenirlik ve geçerlik çalışması. Ankara Üniversitesi Eğitim Bilimleri Fakültesi Dergisi, 39(2), 45-74.

Göka, E., Türkçapar, M. H., Sayar, K., Rashid, T., Dinç, M. ve Çakır, Z. (2020). Kaygı çăğ: salgın zamanlarında ruh sağlı̆̆g. Istanbul: Kapı Yayınları.

Hubbard, J., Realmuto, G. M., Northwood, A. K., ve Masten, A. S. (1995). Comorbidity of psychiatric diagnoses with post traumatic stress disorder in survivors of childhood trauma. Journal of the American Academy of Child and Adolescent Psychiatry, 34, 1167-1173.

Hunter, A.J. \& Chandler, G.E. (1999) Adolescent resilience. Image. Journal of Nursing Scholarship, 31(3), 243-247.

Karaırmak, Ö. (2007). Deprem yaşamış bireylerde psikolojik să̆lamlı̆̆a etki eden kişisel faktörlerin incelenmesi: Bir model test etme çalışması. Yayınlanmamış doktora tezi, Orta Doğu Teknik Üniversitesi, Ankara.

K1lıç, Ş. D. (2014). Üniversite ögrencilerinin yalnızlık ve psikolojik dayanıklllıklarının incelenmesi. Yayınlanmamış yüksek lisans tezi, Atatürk Üniversitesi, Erzurum.

Kumpfer, K.L. (1999). Factors and processes contibuting to resilience: The resilience framework. Glantz, Meyer D. ve Johnson, Jeanette L. (Eds.), Resilience and development positive life adaptations içinde. 179- 225. New York: Kluwer Academic Publishers.

Luthar, S. S. (2006). Resilience in development: a synthesis of research across five decades. D. Cicchetti, \& D. J. Cohen (Ed.). New York: Wiley

Luthar, S. S., Cicchetti, D., ve Becker, B. (2000). The construct of resilience: A critical evaluation and guidelines for future work. Child Development, 71(3), 543-562

Luthar, S. S.; Sawyer, J. A. ve Brown, P. J. (2006). Conceptual issues in studies of resilience. Past, present and future research. Annals New York Academy of Sciences, 1094, 105-115. 
Masten, A.S., Reed, M.G. (2002). Resilience in development. S.R. Snyder and S.J. Lopez (Eds.) The handbook of positive psychology içinde. England: Oxford University Press.

Oktan, V. (2008). Üniversite sınavına hazırlanan ergenlerin psikolojik sağlamlıklarının çeşitli değișkenlere göre incelenmesi. Yayınlanmamıș doktora tezi, Karadeniz Teknik Üniversitesi, Trabzon.

Oktan, V., Odacı, H., ve Berber-Çelik, Ç. (2014). Psikolojik doğum sırasının psikolojik sağlamlığın yordanmasındaki rolünün incelenmesi. Abant İzzet Baysal Üniversitesi Ĕgitim Fakültesi Dergisi, 14(1), 140-152.

Öğülmüş, S. (2001) Bir kişilik özelliği olarak yılmazlık. I. Ulusal Çocuk ve Suç Sempozyumu: Nedenler ve Önleme Çalışmaları, 29-30 Mart, Ankara.

Özcan B. (2005). Anne-babalar boşanmış ve anne-babalart birlikte olan lise ögrencilerinin yılmazlık özellikleri ve koruyucu faktörler açısından karşılaştırılması. Yayınlanmamış yüksek lisans tezi, Ankara Üniversitesi, Ankara.

Özçetin-Üzar, Y.S. ve Hiçdurmaz, D. (2017). Kanser deneyiminde travma sonrası büyüme ve psikolojik sağlamlık. Psikiyatride Güncel Yaklaşımlar, 9(4), 388-397.

Özer, E. (2013). Üniversite öğrencilerinin psikolojik sağlamlık düzeylerinin duygusal zeka ve beş faktör kişilik özellikleri açısından incelenmesi. Yayınlanmamış doktora tezi, Necmettin Erbakan Üniversitesi, Konya.

Özer, E. ve Deniz, M.E. (2014). Üniversite öğrencilerinin psikolojik sağlamlık düzeylerinin duygusal zeka açısından incelenmesi. Illkögrretim Online, 13(4), 1240-1248

Öztürk, H. (2019). Üniversite ögrencilerinde duygu düzenleme stratejileri ile psikolojik sağlamlık arasındaki ilişkinin incelenmesi. Yayınlanmamış yüksek lisans tezi, Hasan Kalyoncu Üniversitesi, Gaziantep.

Parr, D. G.; Montgomery, M. ve DeBell, C. (1998). Flow theory as a model for enhancing student resilience. Professional School Counseling, 1(5), 26-31.

Rabkin, J. G., Remien, R., Katoff, L., ve Williams, J.B.W. (1993). Resilience inadversity among longtermsurvivors of AIDS. Hospital and Community Psychiatry, 44(2), 162-167.

Ramirez, E.R. (2007). Resilience: A new concept analysis. Nursing Forum, 42(2), 73- 82

Sandel, Keranen J. (2007), The effects of trauma exposure, emotional intelligence and positive emotion on resilience. Yayımlanmamış doktora tezi, Fielding Graduate University, ABD.

Seligman, M. E. P. \& Csikszentmihalyi, M. (2000). Positive psychology: an introduction. American Psychologist, 55(1), 5-14.

Secades, X.G., Molinero, O., \& Salguero, A. (2016). Relationship between resilience and coping strategies in competitive sport. Perceptual and Motor Skills, 122(1), 336-349.

Sezgin, K. (2016). Üniversite öğrencilerinin psikolojik sağlamlık ve dindarlık düzeylerinin incelenmesi (Dicle Üniversitesi örneği). Yayınlanmamış yüksek lisans tezi, Dicle Üniversitesi, Diyarbakır.

Sipahioğlu, Ö. (2008). Farklı risk gruplarındaki ergenlerin psikolojik sağlamlıklarının incelenmesi. Yayımlanmamış yüksek lisans tezi, Selçuk Üniversitesi, Konya.

Taşğın E, Çetin F.Ç. (2006). Ergenlerde major depresyon: risk etkenleri, koruyucu etkenler ve dayanıklılık. Çocuk ve Ergen Ruh Sağlığ Dergisi, 13(2), 87-94.

T.C. Milli Eğitim Bakanlığı (2020). Salgın dönemlerinde psikolojik sağlı̆̆ımızı korumak. Ankara: Özel Eğitim ve Rehberlik Hizmetleri Genel Müdürlüğü. 3 Mayıs 20202 tarihinde http://www.meb.gov.tr/meb_iys_dosyalar/2020_03/30112459_ailecocuk.pdf adresinden erişildi. 
Terzi, Ş. (2006). Kendini toparlama gücü ölçeğinin uyarlanması: geçerlik ve güvenirlik çalışmaları. Türk Psikolojik Danışma ve Rehberlik Dergisi, 3(26), 77-86

Terzi, Ş. (2008). Üniversite öğrencilerinin psikolojik dayanıklılıkları ve algıladıkları sosyal destek arasındaki ilişki. Türk Psikolojik Danışma ve Rehberlik Dergisi, 3(29), 1-11.

Tugade, M. M. ve Frederickson, B. L. (2004). Resilient individuals use positive emotions to bounce back from negative emotional experiences. Journal of Personality and Social Psychology, 86, $320-333$.

Winders, S. (2014). From extraordinary invulnerability to ordinary magic: A literature review of resilience. Journal of European Psychology Students, 5(1), 3-9. 